\title{
Hopefulness and suspense in the autoethnographic encounters of teaching in higher education
}

\section{Claudia Mitchell}

I remember hearing far off the sound of the tires of a car on the gravel of the long, straight, open road that my family always referred to as the 'main road'. This main road is some distance from our farm yard, connected by another long and very straight and open lane way. No trees or bushes or anything to block the view of the prairie expanse. For several minutes there is suspense. The tires offer a hopeful sound, breaking the silence, and breaking the monotony of the long summer day of a little girl who longs for something, anything, to happen. First the car is quite a way off. Then it sounds like it is slowing down - and I see that it is turning into our lane way. It stops there, and at that moment I am lost in anticipation. I don't recognize the car. Is it going to come up the lane or is the driver just turning around? Will there be the sound of the wheels speeding up, kicking up a little dust as it heads back down the main road towards town, or will the vehicle slowly make its way up the narrow passage of the lane way, towards the barn and house?

I offer this gravel road memory from my prairie childhood as an example of what might be termed 'the stuff' of autoethnography, evoking questions like: Where do I come from, how did I get here, and indeed, where is here? As Tony Kelly (2008) recounts so effectively in his autoethnography of teaching in a rural school in Nova Scotia, the question, "What are you doing here?" (p.9) is one that is laden with positionality. How do I, in this instance, anticipate the unknown and how do I position myself and the events as hopeful? In this brief essay I consider the role of autoethnography in 'being' and 'becoming' in our teaching in diverse higher education settings. My own settings are, in and of themselves, diverse, ranging from my full-time work at a large university in a cosmopolitan city in Canada to being a teacher (at least on a part-time basis) in universities in Sweden, Ethiopia and South Africa and, most recently, at another Canadian university on its west coast. Following from Appiah's (2006) notion of cosmopolitan citizenship, I find myself, like many of my academic colleagues in South Africa and elsewhere, 
with opportunities to travel to and interact with students and peers in countries that I would never have dreamt of visiting, let alone working in, all those years ago, growing up on farm in the middle of the Canadian prairies in the 1950 and early $1960 \mathrm{~s}$, and listening attentively to the sound of the tires on the gravel road.

As diverse as the settings are, each setting in itself is filled with diversity. The postgraduate course at that west coast Canadian university where I am teaching as I write this, and which draws on the tools of visual autoethnography as central to the course, includes several students from Iran, another from Korea, a student whose mother gets on a boat in Vietnam in 1979 and hopes she will reach Thailand and then Canada, a student from Hong Kong, another from Chile, one from Russia, and a student whose grandparents make their way to the Canadian west from Scotland - but then, alongside these geographic divisions, there are different cultural and experiential divisions that frame the diversity as they arrive at class each day. Several students have very young children and so must always be thinking of childcare and picking up children, a couple are teachers who are preparing for their own diverse school settings that will start up again in a few weeks and so they have a common interest in how they will apply the assignments and so on. How do we anticipate the unique and diverse circumstances of our teaching? What does an autoethnographic stance allow us to do? What difference can the memory of the gravel road, in my case, make to how I approach my teaching, my students, my colleagues and my research? How is it that what I might describe as a memory of convenience allows me to account for what I now want to write about, and how is it a piece of writing that helps me to make meaning of what is, it turns out, a critical feature of my teaching?

There are at least three main points that seem to me to be central to autoethnography in addressing diversity in higher education. The first is in relation to what I call the act of commitment, or consciously doing, telling, and crafting meanings in relation to our teaching experiences. The phenomenologist Max Van Manen is well known for the idea of writing as research where the "writing is the writing" (1990, p.92). I would add to this the idea that it is also the looking at, showing of, and talking about, for example, personal photographs or creating an artistic piece about our own practice that can also contribute to the act of commitment in autoethnographic research. The memory of the sounds of the car tires on the gravel road has been with me for years and I have referred to this memory on several 
occasions. I have used it to talk about the sheer boredom of growing up on a farm (versus the romantic ideal of rurality), to account for the ways that I embrace novelty and travel as perhaps a key aspect of my modus operandi, and to think, of course, about sound itself in our research sees as a multisensory component of our existence (Pink, 2015) and one that should not be overshadowed by the visual.

A second point relates to vulnerability. As I write this essay, several of my doctoral students are in the final hours of completing their own autoethnographies that are also related to higher education. These are moments of vulnerability, both in relation to what they are writing about (themselves and their own teaching), and in relation to the fact that they must put this work out for examination. My work by comparison seems much less vulnerable - but nonetheless it constantly reminds me to ask the question: How can we possibly support this kind of work if we not do it ourselves, and if we do not make ourselves vulnerable? In part it relates to how we respond to the autoethnographic work of our postgraduate students. How do we, often as the first readers of this work, take this vulnerability into account? There are many different aspects of diversity, ranging from race, class, sexual orientation, gender, geography and so on. How do we ask questions that do not close down what are often very revealing aspects of our students' lives? This is of course a critical issue in South Africa, where there remain many racial imbalances, but race is only one part of this, and as I have noted above, diversity embraces many different features of our work.

A third point relates to hopefulness and suspense and the need to use an autoethnographic stance in opening up our teaching. Here the writing about the tires on gravel seems now to capture metaphorically something of the essence of addressing diversity - the unknown, the anticipation, the suspense that in a sense comes with the beginning days of every new course that we might teach. There is never a time that is quite like the beginning, and quite as dreaded as those first days of teaching a new group of students, for me and for many of my colleagues; I take this up elsewhere (Mitchell and Weber, 1999). It is in part because we have no idea what is going to happen. The car at the end of the lane way may indeed speed away, but what if it does turn in? How prepared are we to greet the car, its driver and its passengers?

I used to think of this hopefulness and suspense stance, as I think I could call it, as somewhat haphazard: whatever happens, happens. However, as I work more with autoethnography in my own teaching, I am coming to realize that 
this stance allows us the luxury of finally having a place to locate and make sense of our experiences. As Kathleen Stewart observes, "Auto-ethnography can be a way of doing something different with theory and its relation to experience" (2013, p.659). For example, we might study the responses, both formal and informal, that we receive about our own teaching from former students or even from other faculty members. This could, on the one hand, be read as some version of the question: How did my teaching have an influence on you? Indeed this is a legitimate question in self-study (see for example, Whitehead, 1989). On the other hand, and I think that is what this piece has helped me to frame, is the recognition of the patterns and shapes of those responses. Just as I was compiling this article, one of my former students, now an accomplished playwright, whom I taught when she was in junior high school in rural Nova Scotia a number of decades ago, sent me a piece that she had published in Brick Books, a literary arts magazine. In it she writes wonderfully glowing comments about the impact of my teaching on her writing.

"That first day she introduced herself as she wrote Ms. Mitchell on the board (Ms! - none of our mothers were Ms.) then whirling around she asked, Does anyone here write POETRY? The way she said POETRY made my heart bump against my chest. Before I could put my hand up the class show-off answered, in a tone dripping with disdain, Cathy Banks does. All heads turned in my direction as Ms. Mitchell, beaming, strode down the aisle to my desk. Ms. Banks, she said, I would love to read your poems!

For the next two years I dropped newly minted poems on her desk once or twice a week. She never made positive or negative comments about my halfbaked poems (make no mistake I was a very bad poet) she simply treated each adolescent attempt as a poem. She was not the teacher but the reader and I was not the student but the poet.

Ms. Mitchell never suggested that I cut or change a line or even a word. My poems reminded her of the works of Margaret Atwood, Al Purdy, Earle Birney, Alden Nowlan, P.K. Page, Margaret Avison, Jay Macpherson to name a few. Her response never varied excepting only the name of the poet. She would take me aside in the hall and say, Thank you for your poem Ms. Banks it reminded me of Margaret Atwood's work (or Nowlan, Birney, Page) have you ever read Margaret Atwood (or Purdy, Avison, Macpherson)? Of course I hadn't, so, she would bring me books of poems from her own library and 
thereby introduced me to the works of many of the contemporary Canadian poets of the 1960s." (Banks, 2015, p.1)

Needless to say I was very moved by this writing, recognizing, of course, that I was also benefitting from the superb writing skills of this former student who has gone on to win the Governor General's award for her plays twice in the last five years. When a former doctoral student who is now a teaching colleague asked to read the piece from Brick Books, she responded with the following.

"Fast forward a few years and many of us at McGill could write a similar homage, though perhaps not as poetically. She identifies immediately the qualities of openness, innovation and what-the-heck-let's-try-it-and-see-howit-goes that characterize your teaching (oh, self-proclaimed "I hate teaching" person). The setting of the table for your students to partake of the feast of learning and doing". (Personal communication, August 18, 2015)

Of course not all my former students look at me this way. A dear colleague and former Chair of my department recently recounted how he had to review, as part of his duties as Chair, student evaluations of courses. One, he recalls, of my teaching was from a student who commented that I am given to talking in such a way that I seem to lose my train of thought but that fortunately I always picked up on another train that was going the same way. My reading on these different observations supports the hopefulness and suspense stance, and, at the same time, highlights the place of autoethnography in teaching. How else does one begin to name one's experiences and, even more critically, see the shape of things?

The richness of the diversity of our classrooms - in South Africa and Canada - is not just about the idea of the inclusive curriculum, though that, of course, is a necessary starting point. We cannot (and should not) be able always to predict what is going to work. There should be some suspense. What we can do is commit ourselves to identifying the moments of learning (about ourselves and our students), and recognize the impact of this work on our teaching and scholarship. 


\section{References}

Appiah, K.A. 2006. Cosmopolitanism; ethics in a world of strangers. New York: W.W. Norton \& Company.

Banks, C. 2015. Week 32 - Catherine Banks and poetry. Brick Books. 1

Kelly, T. 2008. Readings from life: rural educators read our rural selves. Unpublished doctoral dissertation, McGill University. Montreal, Qc.

Mitchell, C. and Weber, S. 1999. Reinventing ourselves as teachers: beyond nostalgia. London and New York: The Falmer Press.

Pink, S. 2015. Doing sensory ethnography. London: Sage.

Stewart, K. 2013. An autoethnography of what happens. In Holman Jones, S., Adams, T. and Ellis, C. (Eds), Handbook of autoethnography. Walnut Creek, CA: Left Coast Press, pp.659-668.

Van Manen, M. 1990. Researching lived experience: human science for an action sensitive pedagogy. London, Canada: Althouse Press.

Whitehead, J. 1989. Creating a living educational theory from questions of the kind, 'how do I improve my practice?' Cambridge Journal of Education, 19(1): pp.41-52.

Claudia Mitchell

McGill University

Montreal

Quebec

$\underline{\text { claudia.mitchell@mcgill.ca }}$ 